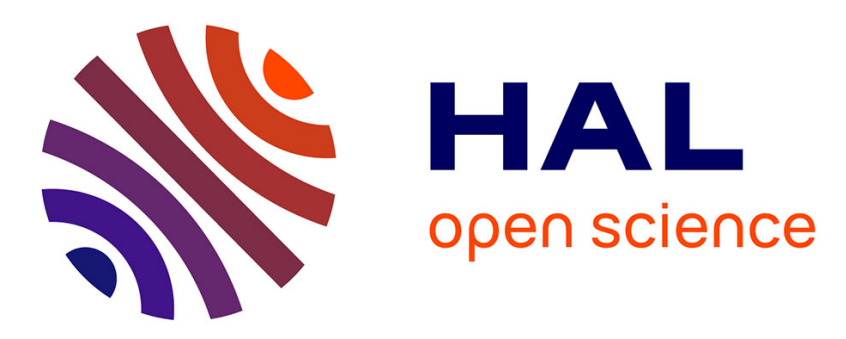

\title{
Characterization of humic substances in highly polluted river sediments by pyrolysis methylation-gas chromatography-mass spectrometry
}

Laurence Mansuy, Yassine Bourezgui, Evelyne Garnier-Zarli, Emilie Jarde, Véronique Réveillé

\section{To cite this version:}

Laurence Mansuy, Yassine Bourezgui, Evelyne Garnier-Zarli, Emilie Jarde, Véronique Réveillé. Characterization of humic substances in highly polluted river sediments by pyrolysis methylationgas chromatography-mass spectrometry. Organic Geochemistry, 2001, 32 (2), pp.223-231. 10.1016/S0146-6380(00)00169-8 . hal-01760398

\section{HAL Id: hal-01760398 \\ https://hal.univ-lorraine.fr/hal-01760398}

Submitted on 6 Apr 2018

HAL is a multi-disciplinary open access archive for the deposit and dissemination of scientific research documents, whether they are published or not. The documents may come from teaching and research institutions in France or abroad, or from public or private research centers.
L'archive ouverte pluridisciplinaire HAL, est destinée au dépôt et à la diffusion de documents scientifiques de niveau recherche, publiés ou non, émanant des établissements d'enseignement et de recherche français ou étrangers, des laboratoires publics ou privés. 


\title{
CHARACTERIZATION OF HUMIC SUBSTANCES IN HIGHLY POLLUTED \\ RIVER SEDIMENTS BY PYROLYSIS METHYLATION - GAS \\ CHROMATOGRAPHY - MASS SPECTROMETRY.
}

Laurence Mansuy', Yassine Bourezgui ${ }^{2}$, Evelyne Garnier-Zarli ${ }^{2}$, Emilie Jardé1, Véronique Réveillé ${ }^{2}$

\author{
'G2R UMR7566 UHP, BP 239 - 54506 Vandœuvre Cedex, \\ ${ }^{2}$ LBSE Université ParisXII Créteil, 61 avenue du Général de Gaulle - 94000 Créteil
}

\begin{abstract}
Humic substances were extracted from two sediment cores sampled in a river on the outskirts of a large city (Deûle near Lille, France) and in its highly polluted oxbow-lake. Humic acids (HA) were characterized by infrared spectroscopy and in situ pyrolysis/methylation-gas chromatography-mass spectrometry. The main results are the important aliphaticity of HA in the oxbow-lake at all depths, mainly due to the presence of a lipid fraction associated with the HA structure. The abundance of sterols in this fraction implies that lipids could originate from the accumulation of sewage in the oxbow-lake. Humic acids of the Deûle sediments show a different trend ; their evolution is characterized by a decrease of the pollutant inputs with increasing depth. The results demonstrate the efficiency of Py-GC-MS in identifying the different organic contributions to HA and in distinguishing natural from anthropogenic sources.
\end{abstract}

\section{INTRODUCTION}

Pollutant discharge, morphological and hydraulic modifications of rivers, deforestation and urbanization of watersheds, induces disturbances of the physical, chemical and biological equilibrium of river systems. This leads to the gradual silting of aquatic systems. In urban areas, this phenomenon is even more marked since rivers receive abundant industrial and 
domestic inputs and rain water from urban run-off. Thus, organic and inorganic deposits can constitute an excellent adsorbent phase for organic and inorganic micropollutants. More specifically, the presence of humic substances in sediments has a significant influence on the immobilization and the possible remobilization (during dredging for instance) of pollutants (Khan \& Schnitzer, 1972; Schlautman \& Morgan, 1993; Gaffney et al., 1996).

In order to further our understanding of the interaction of humic substances with pollutants, it is first essential to characterize them. They have a complex structure reflecting the various origins of organic matter : autochthonous (organic matter synthesized in the aquatic system), allochthonous (terrestrial debris of higher plants) or anthropogenic (that can be the main input in urban areas) (Ishiwatari, 1985; Leenher, 1991; Saiz-Jimenez, 1996). The complexity of these molecules also results from the multiple processes involved in the chemical and biological degradation of the original organic material (Flaig, 1988; Andreux \& MeunierLamy, 1994).

A variety of analytical methods have been employed to characterize humic substances and there is now a growing interest for molecular characterization using degradative methods such as pyrolysis-gas chromatography-mass spectrometry (Py-GC-MS) ( Schnitzer \& Schulten, 1992; Hatcher \& Clifford, 1994; Saiz-Jimenez, 1994; Schulten et al., 1995; Schulten \& Leinweber, 1996 ). Its main advantage lies in the identification of molecular markers characterizing the different organic contributions in soils or sediments. The method is important in the study of polluted soils or sediments since it allows identification of anthropogenic agents (de Leeuw et al., 1986). This technique has been improved with the development of in situ methylation using tetramethylammonium hydroxide (TMAH) which favors the volatilization and the chromatography of polar compounds abundant in humic substances (Challinor, 1989; Hatcher \& Clifford, 1994; Saiz-Jimenez, 1995; McKinney et al., 1998). 
In this paper, we present the results of an investigation on the molecular characterization of organic matter of aquatic sediments in two different systems : a river and its highly polluted oxbow-lake. The aims of the study were to evaluate the ability of in situ methylation Py-GCMS to characterize humic substances in highly polluted sediments, to determine the difference in the organic composition of the river and oxbow-lake sediments and to correlate the Py-GCMS signatures with their environment.

\section{SAMPLES AND METHODS}

\section{Sampling site}

The sediments of a channeled river, the "Deûle", were used as a reference for this study. The Deûle river, located in the North of France, belongs to the Artois-Picardie watershed, and flows through the outskirts of Lille. Because this region is highly industrialized and is extensively used for agriculture, the water quality is poor and the sediments are polluted primarily with cadmium and lead.

A second sediment core was collected in the oxbow-lake of the Deûle river. This $850 \mathrm{~m}$ long and $20 \mathrm{~m}$ wide body of water crosses a downtown section of Lille and an industrial area. It is connected to the Deule river by a narrow channel that allows a reciprocal connection between the two environments depending on the hydrodynamic conditions (Figure 1). The oxbow-lake is fed by the Deûle river at one end and by a spillway which drains the wastewater network of the city at the other end. It also collects the rain water coming from the motorway and the rail-road that overhang the oxbow-lake. Usually, the current goes from the Deûle towards the oxbow-lake and the low run-off speed favors accumulation of sediments and pollutants in the oxbow-lake. However, during heavy showers, the current goes towards the Deûle river since most of the run-off spills into the oxbow-lake. 


\section{Sampling and sample preparation}

Sampling was performed with a core drill in order to get a vertical profile with minimum disturbances. The cores were frozen and cut into $10 \mathrm{~cm}$ layers. Six layers were obtained from the Deûle core (60 cm long) and eight from the oxbow-lake core (80 $\mathrm{cm}$ long). After defrosting, the sediments were dried, sieved at $2 \mathrm{~mm}$, and crushed.

Humic acids (HA) were isolated from the sediments, purified and freeze-dried according to the procedure defined by McCarthy et al. (1979) and Thurman and Malcolm (1981). HA were ultrasonically extracted with dichloromethane in order to recover the lipids often associated with this fraction. The extraction was performed several times until the solvent was colorless. A sample of sewage sludge was also extracted with dichloromethane and the lipid fraction recovered in order to compare its composition with those from the sediment samples.

\section{Analytical methods}

The sediments samples were analyzed for total organic carbon (Walkey \& Black, 1934). In order to characterize the functional groups within the HA, they were analyzed by Fourier transform infrared microspectroscopy. An aliquot was placed between two diamond windows ( $2 \mathrm{~mm}$ diameter, $1 \mathrm{~mm}$ thick) of a compression cell $\left(7.5 \times 5.1 \mathrm{~cm}^{2}\right.$, SpectraTech Int.). After compression of the sample, the top window was removed. The area to be analyzed was selected under the microscope with visible light and a x10 objective. Micro-Fourier transform infrared (FTIR) analysis was performed on a Bruker IFS-88 equinox spectrometer coupled to a Bruker multipurpose infrared microscope which was fitted with a $250 \mu \mathrm{m}$ narrow band MCT detector cooled to $77 \mathrm{~K}$. The standard analytical conditions were $\mathrm{x} 15$ objective, $40-60$ $\mu \mathrm{m}$ diameter infrared spot, 60 scans $(30 \mathrm{~s})$ and spectral resolution of $4 \mathrm{~cm}^{-1}$. Spectra were subtracted from the background measured on a clean diamond window under the same 
analytical conditions. The use of diamond cells avoids the adsorption of water and thespectral shifts often observed when using $\mathrm{KBr}$ pellets [Ruau, 1997 \#53].

Humic acids were then subjected to Py-GC-MS analysis. The samples were methylated in situ with TMAH based on the method of Challinor (1989), Hatcher and Clifford (1994) and Saiz-Jimenez (1995). An approximate 10:1 weight ratio of TMAH:sample was placed in a quartz tube and pyrolyzed at $620^{\circ} \mathrm{C}$ for $15 \mathrm{~s}$ in a CDS 2000 pyroprobe. The pyrolysis products were analyzed by gas chromatography-mass spectrometry (HP 5890 Series II coupled to a HP 5972 mass spectrometer). The temperature of split/splitless injector was $280^{\circ} \mathrm{C}$. The $\mathrm{GC}$ was fitted with a $60 \mathrm{~m}$ J\&W DB-5ms, $0.25 \mathrm{~mm}$ i.d. and a $0.1 \mu \mathrm{m}$ film fused silica column. After cryofocusing, the $\mathrm{GC}$ oven was programmed to $300^{\circ} \mathrm{C}$ at $5^{\circ} \mathrm{C} / \mathrm{min}$. The final temperature was held for $15 \mathrm{~min}$.

Lipid analyses were performed with an HP5890 Series II GC connected to a HP5972 mass spectrometer ; the same GC column was used. The oven temperature was programmed from $40^{\circ} \mathrm{C}$ to $300^{\circ} \mathrm{C}$ at $5^{\circ} \mathrm{C} / \mathrm{min}$ then held at $300^{\circ} \mathrm{C}$ for $15 \mathrm{~min}$. Prior to GC-MS analysis, these fractions were derivatized with bis (trimethylsilyl) trifluoroacetamide (BSTFA+TMS).

\section{RESULTS}

\section{Characteristics of the sediments}

Morphological as well as in situ physicochemical analyses were performed on the two sediment cores. The oxbow-lake core shows a uniform black color all along the profile due to a high total organic carbon (TOC) content ranging from 10 to $15 \%$. The reducing conditions, as revealed by the negative redox potential, are the result of high $\mathrm{O}_{2}$ consumption induced by the microbiological and chemical degradation of organic matter and the insufficient renewal of oxygen from the overlying water. 
The color of the Deûle sediment core varies from gray black greenish in the upper layer $(10 \mathrm{~cm}$ ) to an ochre green color in the deeper layers (up to $60 \mathrm{~cm}$ ). The TOC content varies from $2.5 \%$ in the upper layer to $1 \%$ in the $60 \mathrm{~cm}$ layer. The oxidizing conditions in the river allow a good turnover of the sedimentary organic matter.

\section{Infrared analysis}

Infrared spectra of HA, extracted from the top and bottom sediments of the two cores, are shown in Figure 2. Their interpretation is based on the work of Garcia et al. (1992) and Piccolo et al. (1992). The main absorption bands are : a broad band at $3100-3600 \mathrm{~cm}^{-1}(\mathrm{H}-$ bonded $\mathrm{OH}$ and $\mathrm{NH}$ groups), a slight shoulder at $3000-3100 \mathrm{~cm}^{-1}$ (aromatic C-H stretching), a band at 2800-3000 $\mathrm{cm}^{-1}$ (aliphatic $\mathrm{C}-\mathrm{H}$ stretching), a shoulder or a peak at $1710 \mathrm{~cm}^{-1}(\mathrm{C}=\mathrm{O}$ stretching of $\mathrm{COOH}$ and ketonic carbonyls), a peak or a shoulder at $1590-1700 \mathrm{~cm}^{-1}$ (aromatic $\mathrm{C}=\mathrm{C}$ stretching, $\mathrm{H}$-bonded $\mathrm{C}=\mathrm{O}, \mathrm{NH}_{2}$ deformation), a peak or a shoulder at $1490-1590 \mathrm{~cm}^{-1}$ ( $\mathrm{NH}_{2}$ deformation of amides), a band at $1300-1500 \mathrm{~cm}^{-1}$ (aliphatic $\mathrm{CH}$ deformation).

The infrared spectra of the oxbow-lake HA are similar whatever the depth. They are always characterized by intense aliphatic $\mathrm{CH}$ bands and a significant contribution of $\mathrm{N}$ containing compounds, such as peptides, as revealed by the intense band at $1590-1700 \mathrm{~cm}^{-1}$ concomitant with the band at $1490-1590 \mathrm{~cm}^{-1}$. The broad band at $3100-3600 \mathrm{~cm}^{-1}$ maximizes at $3300 \mathrm{~cm}^{-1}$ due to a significant contribution of $\mathrm{N}-\mathrm{H}$ stretching due to peptides. These features were observed by Piccolo et al. (1992) in HA of sludge-amended soils.

The infrared spectrum of HA from the Deûle upper layer is similar to that of the oxbowlake although the aliphaticity and the $\mathrm{N}$-containing functions are slightly less prominent. These parameters both substantially decrease with increasing depth. The strong absorption at $3400 \mathrm{~cm}^{-1}$ is shifted towards lower frequencies $\left(3300 \mathrm{~cm}^{-1}\right)$ resulting from the decreasing 
The main feature of the pyrograms of the oxbow-lake HA is the significant contribution of steroids (Figure 3). Fatty acids also contribute to the lake HA pyrograms : their distribution is dominated by $n-C_{16}$ and $n-C_{18}$ fatty acids, and to a lesser extent by $n-C_{20}, n-C_{22}, n-C_{24}$ fatty acids. Lignin-derived pyrolysis products are poorly represented. As observed in the infrared spectra (Figure 2), no change in the distribution of the pyrolysis products is observed with the depth.

In contrast, the pyrograms of the Deûle HA show changes with increasing depth (Figure 4). While present, steroids are less abundant than the n-fatty acids. Unlike the oxbow-lake samples, the contribution of lignin-derived products is greater and includes a wide variety of compounds. In the uppermost layer $(10 \mathrm{~cm}$ deep), the P-containing compounds (phosphoric and phosphonic acids) are prominent. With increasing depth, their is a much lower contribution from steroids and n-alkanes. In the deeper layer, the main compounds are phosphoric and phosphonic acids, lignin-derived products and $n-C_{16}$ and $n-C_{18}$ fatty acids. This pyrogram is less complex than that of the oxbow-lake but contains many compounds not yet identified.

\section{Lipid analyses}

Extraction of lipids from the HA yields, on average, $20 \%$ in the oxbow-lake HA and the upper layer of the Deûle HA and less than $8 \%$ from the $80 \mathrm{~cm}$ fraction of the oxbow-lake HA.

The lipid fraction mainly contains n-fatty acids with the same distribution as in the pyrograms of HA and abundant steroids that have been identified as $\mathrm{C}_{27}$ to $\mathrm{C}_{29} 5 \beta$-stanols, and $\mathrm{C}_{27}$ and $\mathrm{C}_{29}$ stanones (Smith et al., 1982). The lipid fraction of the $60 \mathrm{~cm}$ Deûle humic acids contained very low concentrations of steroids.

The $5 \beta$-stanols (more specifically $5 \beta$-cholestan-3$\beta$-ol ; coprostanol) are used as common markers of manured soils (Bull et al., 1998), or domestic waste or human fecal material 
contribution of $\mathrm{N}-\mathrm{H}$ stretching of peptides over the $\mathrm{O}-\mathrm{H}$ stretching of oxygen-containing functional groups.

\section{In situ Py/methylation-GC-MS}

Figures 3 and 4 show the total ion current (TIC) chromatograms of the pyrolysates of HA of the upper and lower parts of the Deûle and oxbow-lake cores. Compounds were identified from their mass spectra (comparison with standards), retention times and literature data (Table 1).

The identified pyrolysis products can be grouped according to their possible origin or source. The two main groups represented in the pyrograms originated from lignin and lipids. The pyrolysis products from lignin, and degraded lignin, include styrene, methoxybenzenes, di- and trimethoxybenzenes, methoxybenzoic acids, di- and trimethoxybenzoic acids, (methoxyphenyl)-propenoic acids, dimethoxybenzaldehydes (Hatcher et al., 1995; Hatcher and Minard, 1996; Klap et al., 1998). Compounds originating from lipids are n-alkanes, nalkenes, fatty acids, dicarboxylic acids and steroids. Fatty acids are mainly n-alkanoic acids ranging from $C_{6}$ to $C_{26}$ with a strong even carbon-numbered signature in the $C_{14}-C_{24}$ region. The $\mathrm{C}_{14}-\mathrm{C}_{18}$ distribution reflects an input from bacteria and plants whereas long chain nalkanoic acids $\left(\mathrm{C}_{22}, \mathrm{C}_{24}, \mathrm{C}_{26}\right)$ are major components of wax coatings on land plant leaves (Cranwell, 1974; Cranwell, 1982; Rieley et al., 1991). Steroids have been tentatively identified based on their mass spectra and literature data (Smith et al., 1982; Bull et al., 1998). The steroid distribution is dominated by $5 \beta$-cholestanol and C29 $5 \beta$-stanol. This class of compound contributes to the aliphaticity of the humic acids observed by infrared microspectroscopy. $\mathrm{N}$-containing compounds identified include an alkyl-indole, $\mathrm{C}_{16}$ and $\mathrm{C}_{18}$ alkylamines. S- and P-containing pyrolysis products were also identified (Table1). 
(Leeming et al., 1997; Sherblom et al., 1997). Coprostanol is produced by the microbial reduction of cholest-5-en-3 $\beta$-ol in the mammalian gut (Macdonald et al., 1983).

Figure 5 compares the steroid fraction extracted from the upper layer of the oxbow-lake humic acid and that extracted from sewage sludge. The sterol chromatograms are virtually identical strongly suggesting that the lipids have originated from sewage accumulated in the oxbow-lake.

\section{DISCUSSION}

IR analyses of the oxbow-lake humic substances suggest that the HA are highly aliphatic. This is attributed mainly to the presence of abundant sterols and fatty acids. This special feature of the oxbow-lake HA can be considered anomalous. Indeed, comparison of the infrared spectra of humic acids and fulvic acids from each sample (not reported in this study) leads to the conclusion that humic acids are much more aliphatic than their fulvic counterparts. This result contradicts the usual definition of humic and fulvic acids based on a difference of aliphaticity and reactivity, fulvic acids being more aliphatic, less aromatic and more reactive than humic acids (Schulten \& Schnitzer, 1995; Gaffney et al., 1996). Highly aliphatic HA have been reported in sewage sludge and in organic-waste-amended soils (Garcia et al., 1991; Piccolo et al., 1992; Garcia et al., 1992). The infrared spectra presented in the cited studies are very similar to those of the oxbow-lake humic acids with an intense aliphatic band and a large contribution of $\mathrm{N}$-containing compounds (amides).

The second interesting feature of HA from the oxbow-lake sediments is the absence of changes in compound distributions with depth. This agrees with the core description, which shows a uniform black color and a high TOC content at all depths. This can be explained by the hydrodynamic conditions of this environment which is subjected to substantial sediment movements during heavy rains since the oxbow-lake is used as a spill-way. Moreover, the 
reducing conditions due to the abundant accumulation of organic matter could stop the diagenetic processes.

The Deûle HA are different. Humic acids from the upper layer have a composition very similar to those of the oxbow-lake. However, the aliphaticity and the nitrogen content decrease with increasing depth mainly due to the decrease $i$, the contribution of sterols and fatty acids and an increasing contribution of lignin-derived compounds. The molecular evolution is also associated with a decrease in TOC content with depth.

The similarity in composition of the upper Deûle HA can be explained by the fact that the two systems are connected by a channel that allows sediment inputs from the oxbow-lake towards the river. Thus, organic pollutants issuing from the oxbow-lake can accumulate in the upper layers of the Deûle, especially during rainy weather. The decrease in pollutants, with depth, indicates that the inputs are recent or that there is a better turnover of the organic matter in the river sediments.

This contaminating fraction can be partly extracted with dichloromethane and should not be considered part of the structure of HA. Analysis of the lipid fraction allows us to conclude that the occurrence of $5 \beta$-stanols, which are markers of sewage, indicates an significant input of domestic wastes to the sediments. This is consistent with the use of the oxbow-lake as a spillway for the waste water basin of Lille.

The presence of a lipid fraction in HA is questionable. It may be easily explained by the fact that steroids are hydrophobic and concentrate in HA fractions during the procedure of extraction of humic substances. Many studies report the retention of hydrophobic organic compounds by HA (Khan \& Schnitzer, 1972; Saiz-Jimenez \& de Leeuw, 1986; Mills et al., 1996; Saiz-Jimenez, 1996). Extraction of HA with organic solvent is not efficient enough and the analyses of oxbow-lake HA, after solvent extraction, still indicate a significant amount of sterols in the pyrograms and aliphaticity in the FTIR spectra. The fact that the extraction was 
not fully efficient suggests that these lipids are trapped in the structure of HA and inaccessible to the solvent but pyrolysis can release them. This fraction is then the predominant signature in the pyrograms overlapping the humic signal mainly constituted of lignin-derived units.

\section{CONCLUSION}

The characterization of the Deûle river sediments and those from its oxbow-lake by Py/methylation-GC-MS and GC-MS allowed us to differentiate compounds having a natural origin (terrestrial inputs, such as lignin-derived compounds) from anthropogenic compounds (sterols and to a lesser extent fatty acids). The former belong to the structure of humic acids while the latter are mainly free lipids trapped in the HA structure that cannot be fully recovered by solvent extraction. Detailed analysis of these extracted lipids allowed us to identify the abundant presence of $5 \beta$-stanols which we interpret to be sourced from the accumulation of sewage in the oxbow-lake. These sterols can be used as molecular markers of a specific pollutant (sewage) to organic matter in the sediments and allow us to define the extent of this input in the sediments at different depths in the oxbow-lake and in the connected system (Deûle river). These results show the importance of characterizing the lipid fraction that can provide crucial information on the nature and origin of pollutants, as well as showing that humic substances can incorporate some of the contaminants into their structure.

\section{REFERENCES}

Andreux, F. \& Meunier-Lamy, M. (1994) Genèse et propriétés des molécules humiques. In: Pédologie 2 : Constituants et Propriétés du Sol. (Ed. by M. Bonneau \& B. Souchier), pp. 109-134. Masson. 
Bull, I.D., Van Bergen, P.F., Poulton, P.R. \& Evershed, R.P. (1998) Organic geochemical studies of soils from the Rothamsted Classical Experiments - II, Soils from the Hoosfield Spring Barley Experiment treated with different quantities of manure. Organic Geochemistry, 28, 11-26.

Challinor, J.M. (1989) A pyrolysis-derivatisation-gas chromatography technique for the structural elucidation of some synthetic polymers. Journal of Analytical and Applied Pyrolysis, 16, 323-333.

Cranwell, P.A. (1974) Monocarboxilic acids in lake sediments : indicators derived from terrestrial and aquatic biota, of paleoenvironmental trophic levels. Chemical Geology, 14, 1-14.

Cranwell, P.A. (1982) Lipids of aquatic sediments and sedimenting particulates. Progress in Lipid Research, 21, 271-308.

de Leeuw, J.W., de Leer, E.W.B., Sinninghe Damsté, J.S. \& Schuyl, P.J.W. (1986) Screening of anthropogenic compounds in polluted sediments and soils by flash evaporation/pyrolysis gas chromatography-mass spectrometry. Analytical Chemistry, 58, 1852-1857.

Flaig, W. (1988) Generation of model chemical precursors. In: Humic Substances and their Role in the Environment (Ed. by F. H. Frimmel \& R. F. Christman), pp. 75-92. Wiley, Chichester.

Gaffney, J.S., Marley, N.A. \& Clark, S.B. (1996) Humic and fulvic acids and organic colloidal materials in the environment. In: Humic and Fulvic Acids: Isolation, Structure, and Environmental Role., 651 (Ed. by J. S. Gaffney, N. A. Marley \& S. B. Clark). American Chemical Society, Washington, DC. 
Garcia, C., Hernandez, T. \& Costa, F. (1992) Characterization of humic acids from uncomposted and composted sewage sludge by degradative and non-degradative techniques. Bioresource Technology, 41, 53-57.

Garcia, C., Hernandez, T., Costa, F. \& Polo, A. (1991) Humic substances in composted sewage sludge. Waste Management \& Research, 9, 189-194.

Hatcher, P.G. \& Clifford, D.J. (1994) Flash pyrolysis and in situ methylation of humic acids from soils. Organic Geochemistry, 21, 1081-1092.

Hatcher, P.G. \& Minard, R.D. (1996) Comparison of dehydrogenase polymer (DHP) lignin with native lignin from gymnosperm wood by thermochemolysis using tetramethylammonium hydroxyde (TMAH). Organic Geochemistry, 24, 593-600.

Hatcher, P.G., Nanny, M., Minard, R.D., Dible, S.D. \& Carson, D.M. (1995) Comparison of two thermolytic methods for the analysis of lignin decomposing gymnosperm wood: the $\mathrm{CuO}$ oxidation method and the method of thermochemolysis with tetramethylammonium hydroxide (TMAH). Organic Geochemistry, 23, 881-889.

Ishiwatari, R. (1985) Geochemistry of humic substances in lake sediments. In: Humic Substances in Soil, Sediment and Water. (Ed. by G. R. Aiken, D. M. McKnight \& R. L. Wershaw), pp. 147-180. Wiley\&Sons.

Khan, S.U. \& Schnitzer, M. (1972) The retention of hydrophobic organic compounds by humic acids. Geochimica et Cosmochimica Acta, 36, 745-754.

Klap, V.A., Boon, J.J., Heminga, M.A. \& Van Soelen, J. (1998) Chemical characterization of lignin preparations of fresh and decomposing Spartina anglica by pyrolysis mass spectrometry. Organic Geochemistry, 28, 707-727.

Leeming, R., Latham, V., Rayner, M. \& Nichols, P. (1997) Detecting and distinguishing sources of sewage pollution in australian inland and coastal waters and sediments. In: 
Molecular Markers in Environmental Geochemistry, 671 (Ed. by R.P. Eganhouse). ACS Symposium Series, Washington D.C.

Leenher, J.A. (1991) Organic substance structure that facilitate contaminant transport and transformations. In: Organic Substances in Aquatic Sediment and Sediments in Water. Humics and Soils., 1 (Ed. by R. A. Baker), pp. 3-32., ACS Symposium Series, Washington D.C.

Macdonald, I.A., Bokkenheuser, V.D., Winter, J., McLernon, A.M. \& Mosbach, E.H. (1983) Degradation of steroids in the human gut. Journal of Lipid Research, 24, 675-700.

McCarthy, P., Peterson, M.J., Malcom, R.L. \& Thurman, E.M. (1979) Separation of humic substances by $\mathrm{pH}$ gradient desorption from a hydrophobic resin. Analytical Chemistry, 51, 2041-2043.

McKinney, D.E., Bortiatynski, J.M., Carson, D.M., Clifford, D.J., De Leeuw, J.W. \& Hatcher, P.G. (1998) Tetramethylammonium hydroxide (TMAH) thermochemolysis of the aliphatic biopolymer cutan : insights into the chemical structure. Organic Geochemistry, 24, 641-650.

Mills, M.S., Thurman, E.M., Ertel, J. \& Thorn, K.A. (1996) Organic geochemistry and sources of natural aquatic foams. In: Humic and Fulvic Acids. Isolation, Structure, and Environmental Role., 651, 651 (Ed. by J. S. Gaffney, N. A. Marley \& S. B. Clark). American Chemical Society, Washington, DC.

Piccolo, A., Zacheo, P. \& Genevini, P.G. (1992) Chemical characterization of humic substances extracted from organic-waste-amended soils. Bioresource Technology, 40, 275-282.

Rieley, G., Collier, R.J., Jones, D.M. \& Eglinton, G. (1991) The biogeochemistry of Ellesmere Lake, UK. I. Source correlation of leaf wax inputs to the sedimentary record. Organic Geochemistry, 17, 901-912. 
Ruau O., Landais P. \& Gardette (1997) Quantitative analysis of powdered organic matter by transmission infrared microspectroscopy using a diamond-window compression cell, Fuel, 76, 645-653.

Saiz-Jimenez, C. (1994) Application of pyrolysis-gas chromatography/mass spectrometry to soil chemistry. In: 15th World Congress of Soil Science, pp. 65-84, Acapulco Mexico.

Saiz-Jimenez, C. (1995) Reactivity of the aliphatic moiety in analytical pyrolysis. Organic Geochemistry, 23, 955-961.

Saiz-Jimenez, C. (1996) The chemical structure of humic substances: recent advances. In: Humic Substances in Terrestrial Ecosystems. (Ed. by A. Piccolo). Elsevier Science, Amsterdam.

Saiz-Jimenez, C. \& de Leeuw, J.W. (1986) Chemical characterization of soil organic matter fractions by analytical pyrolysis-gas chromatography-mass spectrometry. Journal of Analytical and Applied Pyrolysis, 9, 99-119.

Schlautman, M.A. \& Morgan, J.J. (1993) Effects of aqueous chemistry on the binding of polycyclic aromatic hydrocarbons by dissolved humic materials. Environmental Science \& Technolology, 27, 961-969.

Schnitzer, M. \& Schulten, H.R. (1992) The analysis of soil organic matter by pyrolysis-field ionization mass spectrometry. Soil Sci. Soc. Am. J., 56, 1811-1817.

Schulten, H.R. \& Leinweber, P. (1996) Characterization of humic substances and soil particles by analytical pyrolysis and computer modeling. Journal of Analytical and Applied Pyrolysis, 38, 1-53.

Schulten, H.R., Sorge, C. \& Schnitzer, M. (1995) Structural studies on soil nitrogen by Curiepoint pyrolysis-gas chromatography/mass spectrometry with nitrogen-selective detection. Biol. Fertil. Soils, 20, 174-184. 
Schulten, H.-R. \& Schnitzer, M. (1995) Three-dimensional models for humic acids and soil organic matter. Naturwissenschaften, 82, 487-498.

Sherblom, P.M., Henry, M.S. \& Kelly, D. (1997) Questions remain in the use of coprostanol and epicoprostanol as domestic waste markers : examples from coastal Florida. In: Molecular Markers in Environmental Geochemistry, 671 (Ed. by E. R.P.). ACS Symposium Series, Washington D.C.

Smith, D.J., Eglinton, G., Morris, R.J. \& Poutanen, E.L. (1982) Aspects of the steroid geochemistry of a recent diatomaceous sediment from the Namibian Shelf. Oceanologica Acta, 5, 365-378.

Thurman, E.M. \& Malcolm, R.L. (1981) Preparative isolation of aquatic humic substances. Environmental Science \&Technology, 15, 463-466.

Walkey, A. \& Black, I.A. (1934) An examination of the Degtareff method for determining soil organic matter, and a proposed modification of the chromic acid titration method. Soil Science, 37, 29-38. 


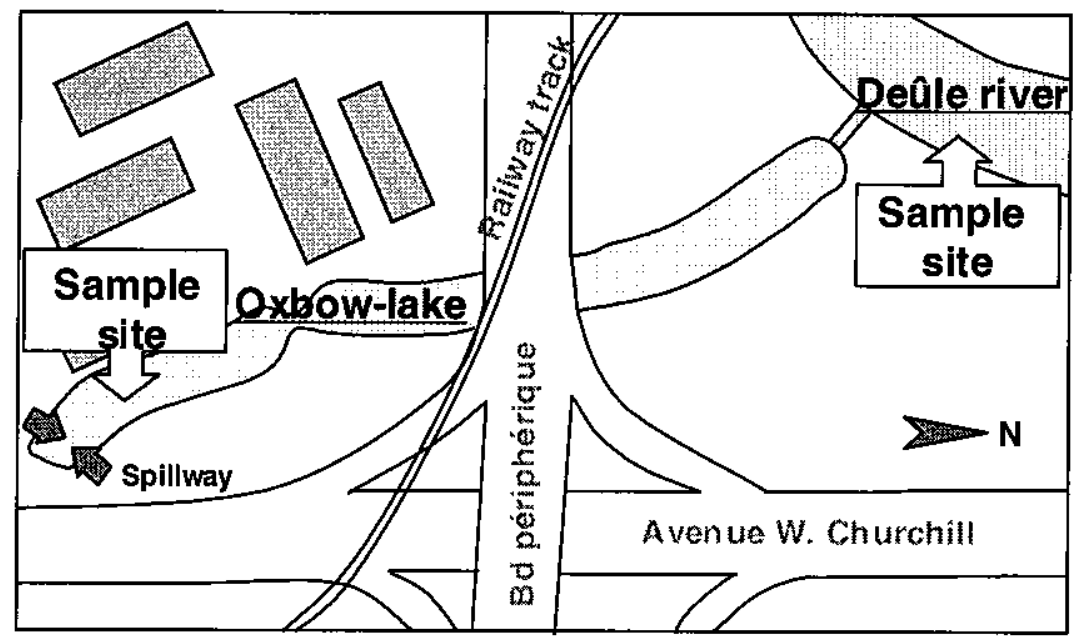

Figure 1 


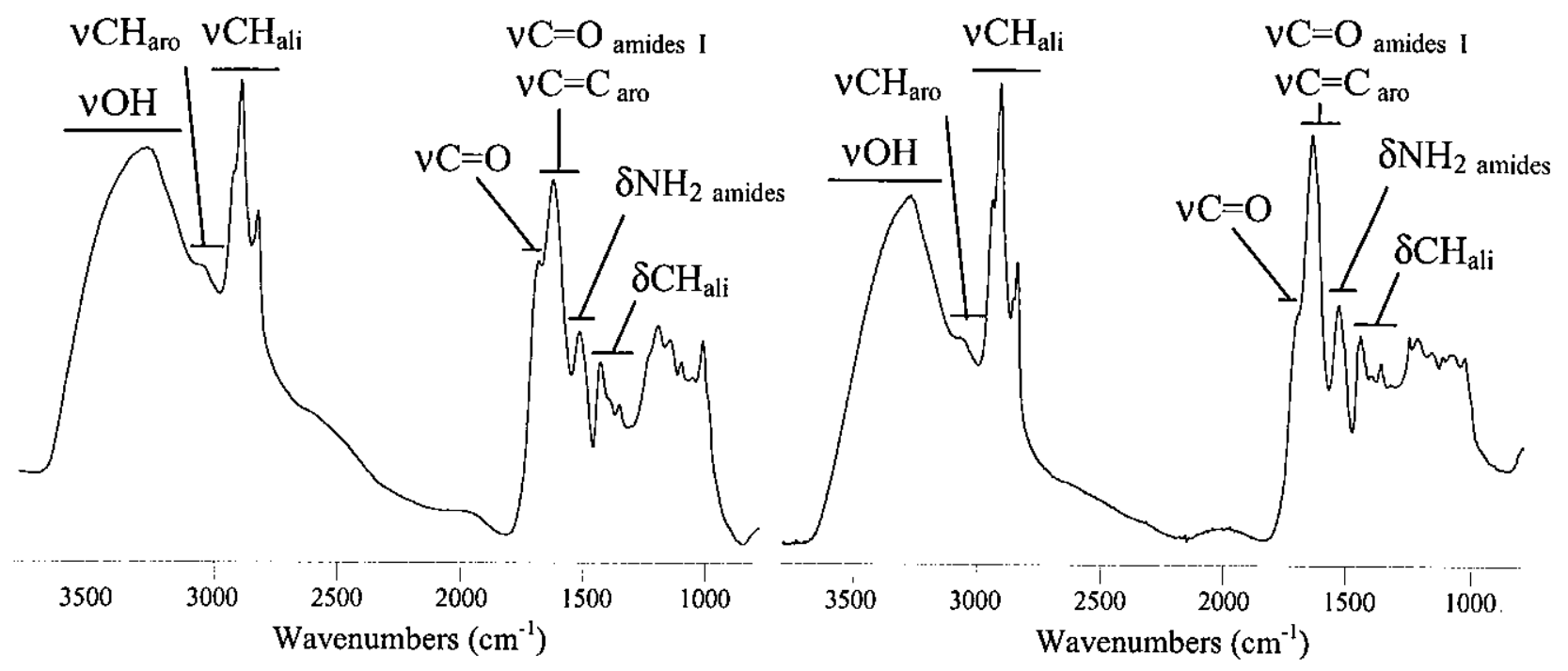

a. Deûle $10 \mathrm{~cm}$ layer

c. Oxbow-lake $10 \mathrm{~cm}$ layer

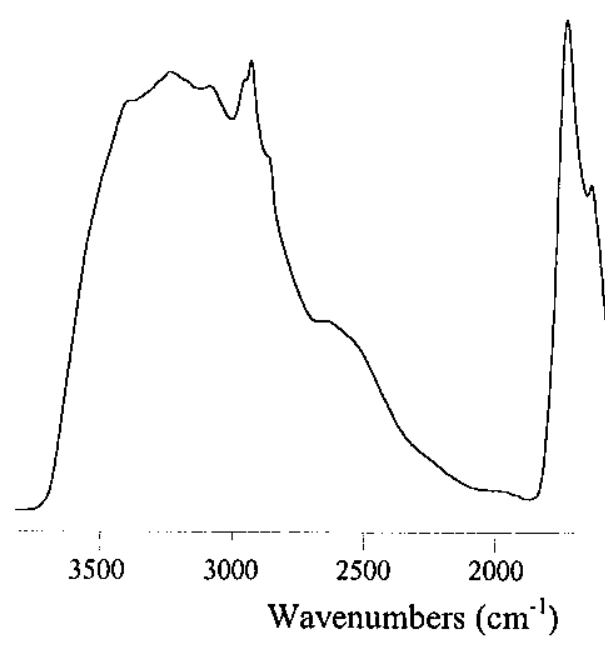

b. Deûle $60 \mathrm{~cm}$ layer

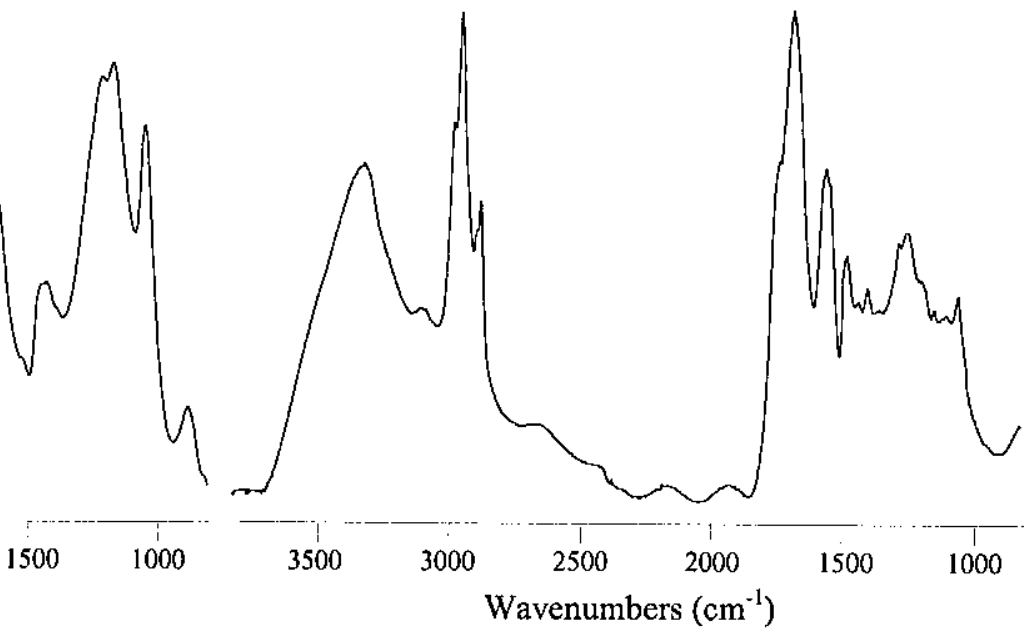

d. Oxbow-lake $80 \mathrm{~cm}$ layer

Figure 2 


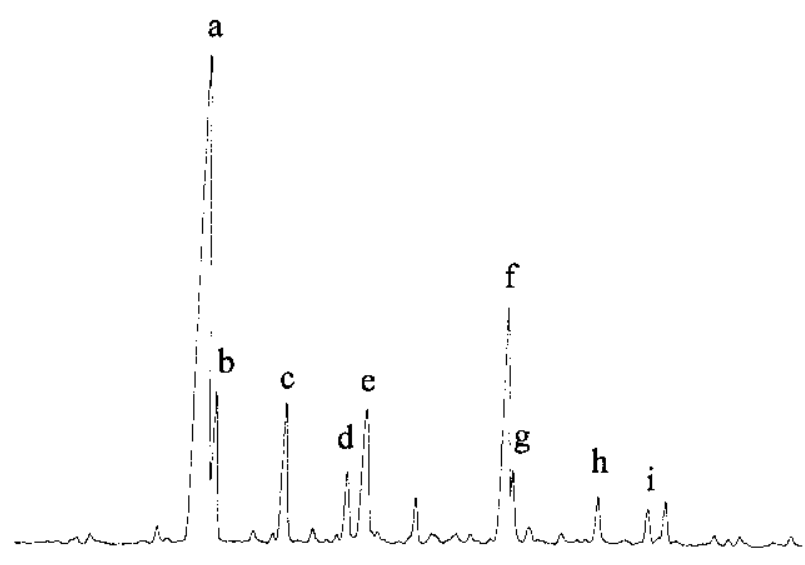

A. Steroids in the extract of humic acids from the oxbow-lake sediments

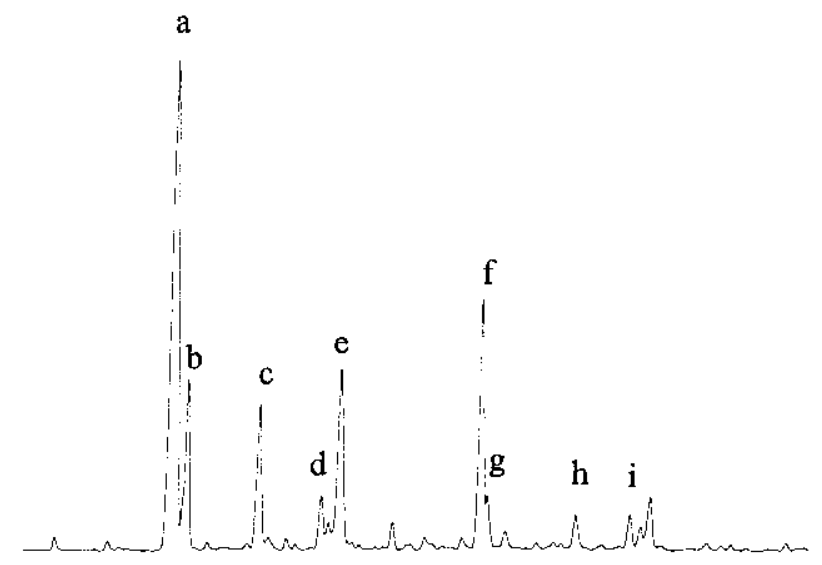

B. Steroids in the extract of a sewage sludge.

Figure 5 


\begin{tabular}{|c|c|c|c|}
\hline Peak & Compound name & Peak & Compound name \\
\hline 1 & Phosphonic acid, dimethyl ester & 46 & Pentadecanoic acid, methyl ester \\
\hline 2 & Styrene & 47 & 1-Octadecene \\
\hline 3 & Phosphoric acid, trimethyl ester & 48 & 1-(Dimethoxyphenyl)-1,2,3-trimethoxypropane \\
\hline 4 & Diethylene glycol dimethyl ether & 49 & Tetradecanoic acid, 12-methyl-, methyl ester \\
\hline 5 & Benzaldehyde & 50 & 1,2,4-Benzenetricarboxylic acid, trimethyl ester \\
\hline 6 & Methylstyrene & 51 & 2-Propenoic acid, 3-(3,4-dimethoxyphenyl)-, \\
\hline 7 & (Methoxymethyl)benzene & & methyl ester \\
\hline 8 & 1-Methoxy-4-methyl-benzene & 52 & Hexadecanoic acid, methyl ester \\
\hline 9 & 2-Butenedioic acid, dimethyl ester & 53 & N, N-Dimethylhexadecylamine \\
\hline 10 & Butanedioic acid, dimethyl ester & 54 & Heptadecanoic acid, methyl ester \\
\hline 11 & Benzoic acid, methyl ester & 55 & Octadecenoic acid, methyl ester \\
\hline 12 & Octanoic acid, methyl ester & 56 & N, N-Dimethyloctadecylamine \\
\hline 13 & 1,4-Dimethoxybenzene & 57 & Octadecanoic acid, methyl ester \\
\hline 14 & Decanal & 58 & Tetracosane \\
\hline 15 & Triethylene glycol dimethyl ether & 59 & Eicosanoic acid, methyl ester \\
\hline 16 & 3,4-Dimethoxytoluene & 60 & Dehydroabietic acid? \\
\hline 17 & 4-Methoxy-benzaldehyde & 61 & Pentacosane \\
\hline 18 & 1-Methylindole & 62 & Heneicosanoic acid, methyl ester \\
\hline 19 & Lignine derivative $(m / z=129)$ & 63 & Hexacosane \\
\hline 20 & Decanoic acid, methyl ester & 64 & Docosanoic acid, methyl ester \\
\hline 21 & Proteinaceous derivative $(\mathrm{m} / \mathrm{z}=98)$ & 65 & Heptacosane \\
\hline 22 & 1,2,4-Trimethoxybenzene & 66 & Tricosanoic acid, methyl ester \\
\hline 23 & 4-Methoxy-benzoic acid, methyl ester & 67 & Docosanoic acid, 2-methoxy-, methyl ester \\
\hline 24 & 2-Propenoic acid, 3-phenyl-, methyl ester & 68 & Octacosane \\
\hline 25 & Dodecanal & 69 & Tetracosanoic acid, methyl ester \\
\hline 26 & 3-methoxy-4,7-dimethyl-1H-isoindole & 70 & Tricosanoic acid, 2-methoxy-, methyl ester \\
\hline 27 & 1,3,5-Trimethoxybenzene & 71 & Sterol 1 \\
\hline 28 & 1,2-Benzenedicarboxylic acid, dimethyl ester & 72 & Sterol 2 \\
\hline 29 & 3,4-Dimethoxybenzaldehyde & 73 & Nonacosane \\
\hline 30 & 1,4-Benzenedicarboxylic acid, dimethyl ester & 74 & Tetracosanoic acid, 2-methoxy-, methyl ester \\
\hline 31 & Dodecanoic acid, methyl ester & 75 & Triacontane \\
\hline 32 & Nonanedioic acid, dimethyl ester & 76 & Hexacosanoic acid, methyl ester \\
\hline 33 & Ethanone, 1-(3,4-dimethoxyphenyl)- & 77 & $5 \beta$-Cholestanol \\
\hline 34 & 3,4-Dimethoxybenzoic acid, methyl ester & 78 & C27-stanol \\
\hline 35 & 1-Hexadecene & 79 & 3ß-Methoxycholest-5-ene \\
\hline 36 & 3,4,5-Trimethoxybenzaldehyde & 80 & Sterol 3 \\
\hline 37 & Benzeneacetic acid, 3,4-dimethoxy-, methyl ester & 81 & $5 \alpha$-Cholestanol \\
\hline 38 & 4,5-Dimethoxy-2-(2-propenyl)phenol & 82 & C28 stanol \\
\hline 39 & Ethanone, 1-(3,4,5-trimethoxyphenyl)- & 83 & Octacosanoic acid, methyl ester \\
\hline 40 & 2-Propenoic acid, 3-(4-methoxyphenyl)-, methyl & 84 & Sterol 4 \\
\hline 41 & 3,4,5-Trimethoxybenzoic acid, methyl ester & 85 & C29 $5 \beta, 3 \beta, 3 \alpha$-stanol \\
\hline 42 & Tetradecanoic acid, methyl ester & 86 & C29 stanol \\
\hline 43 & 2-Propenoic acid, 3-phenyl-, ethyl ester & 87 & 24S-stigmast-5-en-3.beta.-ol \\
\hline 44 & 4-Acetyl-2,3,6-trimethoxytoluene & 88 & Sterol 5 \\
\hline 45 & 1-(Dimethoxyphenyl)-1,2,3-trimethoxypropane & 89 & Sterol 6 \\
\hline
\end{tabular}




\section{CAPTIONS}

Figure 1: Map of sample sites showing the connections between the Deûle river and its oxbow-lake.

Figure 2 : Infrared spectra of humic acids extracted from the Deûle river sediments at depths of $10 \mathrm{~cm}(\mathrm{a})$ and $60 \mathrm{~cm} \mathrm{(b)} \mathrm{and} \mathrm{from} \mathrm{the} \mathrm{oxbow-lake} \mathrm{at} \mathrm{depths} \mathrm{of} 10 \mathrm{~cm}(\mathrm{c})$ and $80 \mathrm{~cm}(\mathrm{~d})$.

Figure 3 : Chromatograms of pyrolyzates of HA extracted from the oxbow-lake sediments at depths of $10 \mathrm{~cm}$ (a) and $80 \mathrm{~cm}$ (b). Peak assignments are reported in Table 1.

Figure 4 : Chromatograms of pyrolyzates of HA extracted from the Deûle river sediments at depths of $10 \mathrm{~cm}$ (a) and $60 \mathrm{~cm}(\mathrm{~b})$. Peak assignments are reported in Table 1.

Figure 5 : Distribution (TIC) of the steroids extracted from oxbow-lake humic acids (A) and extracted from a sewage sludge (B). (a) $5 \beta$-cholestan-3 $\beta$-ol, TMS ; (b) C27- $5 \beta$-stanol, TMS; (c) Coprostan-3-one ; (d) Cholest-5-en-3 $\beta$-ol, TMS ; (e) C28-5 $\beta$-stanol, TMS ; (f) 24-ethylcoprostanol, TMS ; (g) C29 stanol, TMS ; (h) C29-5 $\beta$-stanone ; (i) 24-dimethylcholest-5-en$3 \beta$-ol, TMS.

Table 1 : Identification of peaks in the pyrograms shown in Figure 2. 